\title{
Hidden in Plain Sight: Correspondent Banking in the 1930s
}

\author{
Laura Panza ${ }^{\mathrm{a}}$ and David Merrett ${ }^{\mathrm{b}}$ \\ ${ }^{a}$ Department of Economics, The University of Melbourne, \\ ${ }^{\mathrm{b}}$ Department of Management andMarketing, The University of Melbourne
}

\begin{abstract}
We present novel quantitative evidence on the number and location of correspondent banking relationships in the 1930s, a neglected area of international banking. Our data, collected from Thomas Skinners' Bankers' Almanac, captures over 2000 correspondent banking connections primarily based on London and New York and a smaller cohort of multinational banks. We draw on the new institutional economics and international business literature to explain the relative ubiquity of correspondent banking and the relative scarcity of multinational banks. Our argument that bilateral trade flows drive correspondent banking is tested empirically using an instrumental Poisson pseudo-maximum likelihood estimation.
\end{abstract}

Keywords: correspondent banking; interwar era; instrumental Poisson pseudo-maximum likelihood; international financial centers; multinational banks 


\section{Introduction}

The first wave of globalization (1850-1913) was characterised by an unprecedented increase in international trade and both long and short-term international financial flows. Banks were critically important in financing trade and in arranging payments and collections services, thus acting as intermediaries on behalf of their customers. ${ }^{1}$ For centuries, merchant banks had facilitated international trade and finance through the use of bills of exchange. ${ }^{2}$ By the late nineteenth century they were being challenged by the new joint-stock banks, which also offered both trade finance and payment services, through the co-operation of similar types of banks used as correspondents. ${ }^{3}$

The ubiquity of international correspondent banking in the first half of the twentieth century has resulted in it being hidden in plain sight. For the most part scholars have overlooked this banking activity in preference to researching the evolution of multinational banks. ${ }^{4}$ The work of Battilossi constitutes a notable exception, as it highlights the 'emergence of global interbank networks based on correspondent relationships' before $1914 .^{5}$ Furthermore, interwar writers from the United States and Britain acknowledge that many individual banks had extensive correspondents networks, 'sometimes covering virtually every business centre in the world" and that large banks had 'hundreds of correspondents throughout the world'. However, to the best of our knowledge the available literature has not provided comprehensive evidence on the number and identity of banks with foreign correspondents and their networks for a large number of countries.

In this paper we have been able to offer a quantitative picture encompassing a very large sample of international correspondent banking relationships for the year 1935 by using the data provided by the British publication, the Bankers' Almanac. This directory offers information for over 2000 banks [respondents] whose customers required payments or 
collections from those of other banks [correspondents], located in a foreign country. Collecting data on correspondent banks (CBs) allowed us to gather information also on 146 multinational banks (MNBs), including their identity, nationality, the number of overseas branches and the host countries in which they operated.

The continued use of correspondent banking relationships during the interwar years, alongside the increasing number of multinational banks, raises interesting questions. Specifically, how can we explain the co-existence of arms' length contracting correspondent relations, covering international payments services, alongside the internalisation of banking services, including payments, under ownership within multinational banks? ${ }^{8}$ In this paper we provide some answers to clarify the difference between these two modes of operation, CBs and MNBs, by unbundling the banks' portfolio of products and services. We argue that only financial intermediation required internalisation because it was not possible to sufficiently attenuate opportunism on the part of agents. ${ }^{9}$ Moreover, we note that there are marked differences between the location choices of a country's banks' correspondent partners and its multinational banks' branches. These differences are first explained with respect to the needs of the respondent banks' customers and are then linked to a wider set of factors influencing the location of MNB branches abroad.

This paper proceeds in a number of steps. First, we will discuss the strengths and weaknesses of the Bankers' Almanac as a data source and the criteria used to build our database. This will be followed by a presentation of data of the largest and most dense correspondent banking network in the world at that time. Second, we follow Merrett in applying the reasoning of the new institutional economics (NIE) to explain the continuing use of arms' length contracting in correspondent bank relations rather than any other mode. ${ }^{10}$ As a point of comparison, we speculate about the motivation of MNBs' entry into foreign markets drawing on the insights of Dunning's eclectic paradigm that postulates the importance of banks' ownership 
advantages, welcoming locations and contracting issues. ${ }^{11}$ We will tease out these dynamic issues through a brief case study of Australia. Third, we utilise a gravity model to analyse empirically the drivers of the geographic pattern of CBs and MNBs', adding a wide range of home and host countries explanatory variables. The results and discussion are presented in section 4, which is coupled with a number of robustness checks to test the strength of our findings. We find that bilateral trade flows were the predominant determinant of the location and number of $\mathrm{CBs}$, while trade had little explanatory impact on the number and location of MNBs. Finally, the main results and interpretation of the evidence and empirical modelling are drawn together in the conclusion.

\section{Measuring correspondent banking: Statistical evidence}

How many banks were there in the world in the interwar period and how many of them were engaged in cross border transactions? The data are piecemeal. For instance, the League of Nations' publications on commercial banks covers only 49 countries. ${ }^{12}$ While Jones has provided an encyclopaedic study of British multinational banks across more than a century and a half, ${ }^{13}$ we know less about those from the rest of the world. ${ }^{14}$ Our knowledge is even more limited when it comes to CBs during the interwar era.

With the aim of offering a more complete picture of the international banking network, we have drawn our 1935 data from Thomas Skinners' Banker's Almanac Year Book 1936-37. This source provides comprehensive coverage of banks from 94 countries engaged in international banking, the majority of whose inter-bank dealings were channelled via the City of London and New York, through the use either of larger banks operating there as correspondents or in some cases of non-British banks having their own offices there. ${ }^{15}$

The Bankers' Almanac was first published in London in $1844 .{ }^{16}$ Originally focusing on British banks, its coverage expanded from the early 1890s to include foreign banks who were 
using British and foreign banks domiciled in London as correspondents. We are aware that this source has some weaknesses. For example Nishimura is critical of its imprecise classification of domestic banks types and points to its incompleteness in recording bank numbers across the second half of the nineteenth century. However, he also acknowledges that 'it is the only exhaustive survey of banks in the period and the results obtained form it are unlikely to be very far from the mark. ${ }^{17}$ Scholars using the Bankers' Almanac as a source for international banking have been more supportive. For instance, Battilossi confirms its accuracy before 1914 by cross-checking it with other contemporary sources about British, French and German MNBs. ${ }^{18}$ Mollan, writing about the first half of the twentieth century, expresses concerns about the lack of validation of the degree of activity of CB relationships, pointing that the source gives 'nothing of the precise nature of the correspondent activity that did occur. ${ }^{19}$ However, he concludes that 'the correspondent relationships described in the Bankers' Almanac were meaningful, because the information listed ... was designed to be of practical use for bankers." 20

While we are unaware of any sources against which the Bankers' Almanac in the 1930s can be cross-checked, we have reason to believe that the coverage of international banking relationships reported had improved significantly by the inter-war period. In the 1901 and 1917 editions London banks were being urged to supply 'the particulars of those they represent in London. ${ }^{21}$ There were no further requests to do so in inter-war editions, and the number of international banks listed grew strongly. ${ }^{22}$ The information in the Bankers' Almanac, which from the mid-1920s included an easier finding aid to the location of foreign banks and their branches, had become a critically important facilitator of the international correspondent banking network. There were network effects, as the more banks that registered their details, the greater the benefits to other banks to engage as CBs. 
We argue that capturing the number and location of banks participating in CB relationships operating through London, and to a lesser extent New York and other international financial centres, is an important metric of international banking for the following reasons. First it highlights the continued dominance of the City of London in key trade related financial markets up to the Second World War. For instance, London banks handled nearly three times the value of acceptances as those in New York and 14 times that of Paris-based banks in 1935..$^{23}$ Moreover, London had emerged as the world's premier foreign exchange market in the inter-war period. ${ }^{24}$ Second, as argued by Michie 'through London....many countries of the world settled their transactions with each other, especially if the volume of business was insufficient to justify direct links', that city being 'a central clearing house to which all banks were connected' ${ }^{25}$

The construction of our dataset requires some clarification. Our aim is to collect data on banks engaged in $\mathrm{CB}$ relationship as respondents and correspondents identifying the nationality of both parties. We exclude entries that were not clearly designated as banks, such as merchant houses and private banks, and those, such as merchant banks, which did not state the names of their counter-parties. Banks that used generic descriptions of their CBs such as 'London bankers' were also excluded, as we were not able to quantify them. Non-British banks with branches in London acting as CBs for other foreign banks have been are allocated according to their country of origin. If a respondent bank had multiple correspondents in another country, say London or New York, we count each one. ${ }^{26}$ This allows us to capture their number and to account for each country-to-country transaction underlying the $\mathrm{CB}$ relationships. We include in our analysis thirty-eight central banks because they used banks in London and New York as agents to provide banking services, such as access to clearing houses. ${ }^{27}$ Finally, less than 20 of the 2007 banks engaged in CB relationships listed in the Bankers' Almanac were subsidiaries or affiliates of other banks. Where the parent 
organizations did not include the subsidiaries' CB relationship in their own entries we have treated them as separate data points.

We are confident that the shock of the Depression and associated disturbances in financial markets would not invalidate the reliability of the data drawn from the Bankers' Almanac as a robust measure of CBs and MNBs during the interwar period for various reasons. First, while world trade shrank in terms of value, there is little evidence of changes in the direction of trade between countries that would have reshaped the pattern of $\mathrm{CB}$ relationships. The reduced volume of trade still required the services of bank payments and collections systems. Specifically, bilateral trade transactions, albeit diminished in value, continued to run along the same channels as existed in 1928. Our bilateral trade data of 1540 country-pairs show that more than 96 per cent of the 1928 trade pairs were replicated in 1935, and that there was a significant increase in new trade partners in 1935 relative to $1928 .{ }^{28}$ Second, the banking system had lost little of its capacity to settle international payments during the 1930s. In fact, most bank failures were resolved quickly by government action. ${ }^{29}$ While the number of banks fell by around a third, 90 per cent of this reduction (of mainly small unit banks) was located in the US. Moreover, the number of banks insured with the Federal Reserve Board system had risen significantly by 1935 . The bulk of the other ten per cent of failures were in Romania, Hungary, Italy and Japan, mostly concentrated amongst the smaller banks. ${ }^{30}$

Despite being 'hidden in plain sight' studying the role of $\mathrm{CB}$ as a banking institution during the interwar era is of key importance. The volume of the transactions handled by CBs not only was considerable, but was also relevant economically, as it fed into countries' capital account, so having further macroeconomic implications. CBs were a critical link in the chain of international transactions, including foreign exchange markets. Exactly because of this significant intermediary role they played, understanding their role in payment settlements can 
contribute in shedding light on the tight link between the collapse of international trade and the collapse of the financial sector during the interwar period. ${ }^{31}$

\subsection{Data}

The Bankers' Almanac identifies 2007 banks from 94 countries the utilised the services of foreign correspondents. In Table 1 we have reduced the number of observations to 1910 banks from the 57 countries for whom we could gather the various metrics required for the empirical testing as will be discussed in Section 3 below. In so doing the number of $\mathrm{CB}$ observations has fallen by less than five per cent. As we can see in column 3, while the vast majority of banks had a CB in London and/or New York, the Almanac provides information also about $\mathrm{CB}$ in other cities. ${ }^{32}$

[Table 1 around here]

Table 1 provides four types of information First, it shows the number of banks from each country that use foreign correspondents. Second, it shows the number of foreign correspondents used by those banks. Thirdly, we can identify the number of foreign banks that have used that country's banks as their correspondent. For instance, 17 of Argentina's banks had 32 foreign CBs. However, only five of those Argentinian banks were used as correspondents by foreign banks. Finally, it shows the number of MNBs, 133, from 33 of the 57 countries. In our example, four of Argentina's banks were multinationals.

In 1935 there were 1910 respondent banks using more than 4000 counter-party banks as CBs. What is of particular interest are the marked differences between countries in the number of their CBs and the number of foreign banks using their banks as CBs. For instance, banks in the United Kingdom and the USA account for 79 per cent of the total number of CB relationships. In contrast, banks domiciled in those countries made up only 12 per cent of respondent $\mathrm{CB}$ relationships. 
[Table 2 around here]

In Table 2 the banks are further sorted into regions as defined in the League of Nations' Network of International Trade in preparation for the empirical testing. The Table shows the overwhelming importance of banks located in Europe in $\mathrm{CB}$ relationships, representing around three-quarters of the total (column II). Around 60 per cent of CBs from other regions used a European counter-party (column IV) and European banks had links with nearly 80 per cent of CBs in the rest of the world (column III). North America, the USA and Canada, run a distant second with only 13 per cent of all CBs (column II). North American banks made less use of the external networks, only ten per cent (Column III) but attracted 37 per cent of CB relations from the rest of the world (Column IV).

By comparison, MNBs made up a small minority of the banks engaged in cross border banking, only seven per cent of those with CBs (Column VI). Not only are the number of banks engaged as CBs far greater that those opening branches abroad as MNBs but they are located in different countries and regions. As with CBs, Europe was the dominant provider of MNBs, two-thirds of the total, with 85 per cent of all offshore branches. North America lagged far behind the leaders in terms of branches both hosted and owned (columns VII and VIII). The rest originated in Asia, Latin America, and Oceania. Two regions, Africa and Oceania received far more foreign branches than their banks established abroad, while the opposite is true for Europe. While, as will be argued below, CBs followed bilateral trade flows there was no such connection to explain the locational choices with respect to MNBs. MNBs from leading European countries such as Britain, France, Holland, Portugal and Spain were disproportionately located in their colonies.

\section{Explaining the ubiquity of correspondent relationships}


Why did so many banks participate in the global banking system as CBs? As shown in Table 3, the global economy's substantial flows of trade, remittances of profits from multinationals and interest payments on sovereign debt in different countries required the services of banks at either end of the transaction.

\section{[Table 3 around here]}

The short answer is that despite increasing trade barriers and capital controls in the 1930s few countries in the world withdrew from cross border trade or capital transfers. Demand was sustained. The costs of participation by individual banks was decreased, as Michie explains, by a tiering of both $\mathrm{CB}$ providers, which acted on behalf of smaller respondents, and collection points, the financial centres. ${ }^{33}$ Using a correspondent rather than opening a branch to make a payment or collection would seem to be an obvious choice.

A more thorough explanation of the number of banks using CBs and the countries involved in such network can be obtained by investigating the multi-product nature of banking business and the optimal form of contracting with agents for each bank type. ${ }^{34}$ Commercial banks offer two types of services to their customers ${ }^{35}$ : first, payment services both domestic and international, and, second, intermediation services where banks bring together borrowers with savers 'by transforming the characteristics (maturity, size, liquidity, risk) desired by the former into to ones acceptable to the latter. ${ }^{36}$ The different bundle of services has profoundly important implications for the 'make or buy' decision: compute the relative costs of undertaking the production or hiring an agent to produce it on the banks' behalf. As Osterberg and Thomson point out correspondent banking is a purchase of an input from another bank as part of its production process providing service to its own customers. ${ }^{37}$

The success of CB relationships was critically dependent upon the principal, the respondent bank, being able to have a high degree of certainty about the correspondent's reliability to 
fulfil its side of the bargain. Merrett has shown that the CB system was an extremely efficient institutional form of handling payment claims across the globe. ${ }^{38}$ The respondent bank, the principal, could write, monitor and enforce a contract undertaken by the correspondent for a number of reasons. First, the task itself was straightforward, as there was no ambiguity that could give rise to 'moral hazard' or 'adverse selection' on the part of the correspondent bank. Second, the documents used in the financing of international trade, bills of exchange and so on, had a long pedigree and were used universally in international trade, giving rise to standardised contracts. Third, bankers had rich information about counter-party banks in other countries with whom they were obliged to deal on behalf of their customers. Bankers' almanacs such as the one we have used provided information about the bank's board of directors, its balance sheet, the address of its branches, the names of its own correspondents and so on. Fourth, the bills accepted by banks were usually rediscounted in international financial markets such as London and New York, thus providing a creditworthiness check of the issuer. Ultimately, the contracts entered into a correspondent relationship were enforceable either in the courts or by arbitration. ${ }^{39}$

Historical contextualisation explains how such complete contracts were able to be employed in hundreds of thousands of payment exchanges across national borders, institutional regimes, languages and cultures at any point in time. Long distance international trade had co-evolved with bills of exchange as its central payments' mechanism. The growing numbers of commercial banks in the late nineteenth century also adopted these methods and legal codes of international payments that had been developed by merchants and bankers over preceding centuries. As we have argued above, the system worked well because of the rich amount of information available to participant banks about their counterparties, repeated transactions could build trust. Every bank could execute the exchange at minimal costs because they all used the same set of 'principles' of banking and the same bookkeeping 
methodologies. Moreover, it was difficult to disguise one's financial strength for long and if a bank was known to have cheated there would have been both reputational and financial consequences.

Using a CB offered important operational advantages. The number, identity and location of CBs used was set by the international transactions of the respondent's customers and by the banking arrangements of their counterparties in the host countries. Data presented in Table 4 suggests that many of the bilateral country to country trade flow were of modest size. Nearly a half of the 1518 inter-country trades were of US\$3m or less. The bank-specific transfers within those countries may have been much smaller and irregular. The size of the network could be extended and contracted at will, existing CB relationship could lie dormant until they were needed again. Contact could be made with a new or existing $\mathrm{CB}$ via a cable message or by post. Moreover, the marginal costs of opening $\mathrm{CB}$ relationships were extremely low. The respondent bank paid the $\mathrm{CB}$ for its services, sometimes by making a deposit that was usually offset by a reciprocal sum deposited by the respondent, Nostro and Vostro accounts, or via fees. ${ }^{40}$ These charges were passed back to the respondent's customers. We can assume that low contracting and operational costs encouraged respondents to purchase intermediate services of payments at a lower costs via a $\mathrm{CB}$ than producing them in-house via opening a branch. ${ }^{41}$

[Table 4 around here]

CB networks operated with a form of governance that was arms' length contracting. ${ }^{42} \mathrm{MNBs}$ by definition internalised their international activities under common ownership and managed their employees directly. Following our reasoning used above, negotiating, writing and enforcing contracts with 'agents' (a bank in the host country operating as a franchisee), in 
order to conduct the bundle of intermediation and payments in foreign countries on their behalf, would be virtually impossible. This is because the behaviour of the agents would be unobservable to the principal and the shifting 'state of the world' would make it difficult to judge the amount of effort being undertaken by the agent.

If banks wanted to compete overseas as banks of deposit the logic of contracting suggests that they should have operated as multinationals. The literature on the determinants of pre-WWII multinational banking, with the exception of Battilossi, is more descriptive than analytic. ${ }^{43}$ What would motivate them to venture abroad and where? A host of considerations come into play, ranging from whether they had a competitive advantage to take abroad, to the level of competition they would face from local banks, ${ }^{44}$ and to the degree of support or restriction received from home and/or host governments. ${ }^{45}$

Our data clearly indicates that while CB was a standardised product, the MNB list in the Bankers' Almanac suggests that they were a 'mixed bag'. While there were some large MNBs in terms of branch numbers and geographic scope, most were small. For instance, the average number of countries entered was less than four, the median number of branches was two and the average was 14 . Only a handful of banks had 'retail' networks of more than 20 branches in any host and 77 were 'free-standing' with only a head office that usually played a critical role in the bank's operations but did not engage in retail banking at home.

\section{Case study}

The dynamics of bank strategies with respect to international operations can be illustrated by the case of Australian banks. Australia, a British colony, was one of the earliest hosts to British multinational banks. ${ }^{46}$ However, the first mover advantages they enjoyed were quickly competed away by a growing number of local banks. The last British MNB entered in

1863. ${ }^{47}$ Local rivals opened branches in London throughout the second half of the nineteenth 
century matching the range of services offered. These Australian banks were treated as 'British' banks in the City of London. ${ }^{48}$ For the most part, banks operating in Australia did not extend their branch networks elsewhere. The local banking environment did not hone skills that would have enabled them to compete with the established 'Exchange Banks' in Asia. ${ }^{49}$ More welcoming markets lay closer to home, New Zealand, Fiji and Papua, which were entered in the mid-nineteenth century, 1880 and 1901, respectively. ${ }^{50}$ There were strong attractions: all were British possessions at time of entry; there were few or no competitors at time of entry; and governments and/or important local customers wanted banking services in these territories. $^{51}$

Australian banks showed little inclination to become MNBs in the first half of the twentieth century. They were highly risk averse after the widespread banking collapses in the $1890 \mathrm{~s}$, they colluded on interest rates and worked hard to deny entry to foreign banks. The entry of a few banks from New Zealand, France and Japan were tolerated as each operated on the fringes of the system not offering retail banking services. Local banks had the implicit support of the government to deny entry of foreign banks from the 1920s up to WWII, as well as their threat to refuse any foreign bank access to the cheque clearing system. ${ }^{52}$

The engagement of Australian banks with the rest of the world was primarily through correspondent relationships. ${ }^{53}$ The principal driver of the growth and diversification of CBs was the changing nature of Australia's trading relations with the rest of the world from the late nineteenth century. Continental and later Japanese buyers of wool became more important than those from Britain, and the market for wool relocated to Australia around the turn of the century. ${ }^{54}$ The wool trade was the attraction for foreign banks, the first to arrive was France's Comptoir d'Escompte de Paris in 1881 and later, in 1915, Japan's Yokohama Specie Bank. ${ }^{55}$ More generally, the number of countries with whom Australia traded rose from 82 in 1910 to 137 by $1935-36 .{ }^{56}$ Australian banks expanded their correspondent 
networks accordingly. Archival records of three British banks operating in Australia show that their correspondent networks covered the Continent, the Americas, the Far East and Africa by the mid-1880s. The number and density of CB relationships had risen sharply by WWI. $^{57}$

The same archival material provides insights into the profitability of $\mathrm{CB}$ relationships. Internal bank records suggest that these banks' charges and associated foreign exchanges fees were one per cent of the monies transferred by CBs. Applying this number to the total balance of payments yields a figure of $£$ A2.65m in 1935 for all banks. ${ }^{58}$ This is one a third of the net interest margin earned from local financial intermediation, and greatly exceeded the $£$ A0.8m resulting from the combination fixed charges of operating an account and fees, 'inland exchange', levied on check collections. Unlike CB operations the internal payments system ran at a considerable loss. ${ }^{59}$ While these results might not hold across all countries, they are suggestive that revenues from international $\mathrm{CB}$ business were an important contributor to the fortunes of domestic banks operating in open economies.

\section{Empirical testing}

In Section 3 we argued why CBs were particularly well suited to the provision of international payments services. The advantages stemmed from the ability to write and enforce a complete contract with the providers, together with operational efficiencies, and large numbers of banks in other countries that could act as counter-parties. Our data (Table 2) confirms Michie's argument that leading financial centres such as London and New York acted as focal points in a global system.

Having established why CBs were the most effective mode of providing international payments, we will provide an explanation of the numbers and geographic location of CBs by employing a gravity model. This methodology has been extensively used to investigate the 
determinants of international trade, financial flows and FDI, both within a historical and contemporary context. ${ }^{60} \mathrm{We}$ believe that the gravity framework can be effectively used to explore also the determinants of CBs, as they acted as key intermediaries for the settlement of international trade and finance transactions. As such, we expect geographical, institutional and political factors to impact $\mathrm{CB}$ locations. For instance, as it is well established in the gravity literature, we expect that geographical distance between two countries and/or remoteness would reduce the likelihood of establishing CBs due to higher transaction costs. On the other hand, market size of home and host countries and trade links typically have been found to have a positive impact on banks' propensity to invest in MNBs. ${ }^{61}$

In accordance with gravity models, one of our key variables of interest is trade. International trade theory predicts that a country's trade patterns are shaped by its underlying comparative advantage, in turn determined by combinations of the abundance of capital, labour and land. It follows that the demand for payments services from all banks in a country would stem from a common set of counter-party countries and so would face broadly similar market, institutional and political risks when venturing abroad.

We will further argue that there was no effective alternative to CBs as mode of international payment. While the provision of payments services via $\mathrm{CB}$ relationships was a low risk and low cost operation, venturing abroad as a MNB was far more problematic because of the multiple risks facing new entrants into foreign markets. These stem from the low probability of a bank having the necessary resources and capabilities to create a sustainable competitive advantage in a foreign market. ${ }^{62}$ The multiple difficulties in operating abroad captured by the rubric of 'liability of foreignness' and 'psychic distance' of the international business literature reflecting the differences between countries' institutions, stages of development, government policies towards banks, language and culture. 
The small numbers of MNBs in our data set suggests that whatever the attractions of branching abroad the costs of entering and operating in foreign markets had deterred most banks. By comparison, almost any bank in the world could provide an acceptable level of service as $\mathrm{CB}$. Another reason for the ubiquity of $\mathrm{CBs}$ was that the multiple barriers to entry facing MNBs did not come into play in the delivery of their service. We extend our analysis in the gravity model to see what factors determine the location of MNBs and their branches.

We have used country-based macro data as the unit of analysis to explore the motivation for banks' involvement in international business. We argue that when the population of banks are aggregated by country their choice set is bounded by country characteristics. For instance, as during the interwar era the pattern of trade between countries was shaped by relative factor endowments, as postulated by Hecksher-Ohlin's principle of comparative advantage, we would expect $\mathrm{CB}$ respondents in country A to face the same opportunity of establishing a $\mathrm{CB}$ relationships within the same set of trading partners. Secondly, we identify country-specific factors as key determinants of the incentives and opportunities to operate as MNBs. Consequently, country-based macro variables are co-dependent with micro-measures in explaining choice the geographic locations of CBs and MNBs.

From our data we generate a matrix matching country-pairs banks with a range of home and host characteristics. This implies that our econometric results are able to provide insights on the determinants of banks' choices on average, given the constraints/facilitations offered by their home country. While this strategy has the drawback of losing details about bank-specific decisions, we believe that it nevertheless constitutes a suitable framework as banks' choices were heavily shaped by national policies and regulations and by the intensity of trade linkages among countries. ${ }^{63}$

\section{Dependent variables}


Beyond bilateral trade flows, labelled $T_{i j}$, we identify a number of determinants of banks' expansion across borders. Subscripts $i$ and $j$ refer to home and partner countries, respectively. The dependent variables include:

$Y_{i}$ and $Y_{j}$ : the size of home (i) and host (j) markets, proxied by GDP per capita at various points in time: 1928, 1935, and 1931-4;

IFC: is a dummy to identify the existence of an international financial centre. This captures the role of global money market centres such as London, New York and Paris in influencing the location and nature of international banking mode choice. Specifically, it identifies countries with a large number of banks and important foreign exchange and securities markets, thus offering a deep and liquid market for short-term instruments. The dummy IFC has been assigned relying on Kindleberger's definition of international financial centre as 'a centre that possess the highly specialised functions of lending abroad and serving as a clearinghouse for payments among countries', as quoted in Reed. Specifically, we follow Reed's ranking of the ten main international financial centres in 1935, whose choice is based on a rank score computed empirically using hierarchical cluster and multiple discriminant analysis. ${ }^{64} \mathrm{We}$ add a dummy of one if these cities were host to CBs or home to a MNB and zero otherwise. In the robustness section we also test the importance of the host country containing a major international financial centre on the MNB branching decisions.

$C O L_{i j}$ is a dummy variable that takes the value one if $i$ and $j$ have colonial ties.

$L A N_{i j}$ is a dummy variable that takes the value one if $i$ or $j$ and $j$ share the same language. It is assigned taking into account a country's language(s) used by government and commercial elites. For example India, while having a multiplicity of vernacular languages, would have conducted much of its international trade and financial transactions in English. 
$E R_{i j}$ is a dummy variable that takes the value one if the exchange rate between $i$ and $j$ was fixed, that is in the case when both countries belonged to the same currency bloc or if they both adhered to the gold standard. This has been assigned following Eichengreen and Irwin. ${ }^{65}$ $D_{i j}$ is the geographical distance between $i$ and $j$.

$R E M_{i}$ is an index for remoteness. This is computed following Melitz as country $i$ 's outputweighted average distance from the rest of the world. ${ }^{66}$ Specifically:

$R E M_{i}=\sum_{j=1}^{C} \quad x_{j} D_{i j}, \quad x_{j=} \frac{Y j}{Y w-Y i} \quad i \neq j$

where $C$ is the number of countries and $x_{j}$ the weight of country $j$ 's GDP in global GDP.

Data on the number and location of $\mathrm{CB}$ and MNB banks and branches are from the The Bankers' Almanac. ${ }^{67}$ Population and GDP data are from Mitchell ${ }^{68}$ and from Maddison's database. ${ }^{69}$ As GDP data are unavailable for some of the countries listed in Skinner's Almanac, our sample is reduced to banks from 57 countries (see Appendix, Table A1). However, this loss of data is minimal since it concerns only small countries with limited bank networks. While the sample reduced by 40 per cent, it provides coverage of 95 and 92 per cent of the total CBs and MNBs, respectively. The League of Nations' Network of World Trade $^{70}$ provided information about bilateral trade flows between the 57 countries in 1928 and 1935 and the identification of colonial linkages.

We specify separate gravity equations for each dependent variable (CBs and $\mathrm{MNBs}$ ) represented by the following equation:

$E\left(x_{i j}\right)=\alpha_{0} Y_{i}^{\alpha 1} Y_{j t}^{\alpha 3} Z_{i j t}^{\beta} e_{i j t}$

In the case of $\mathrm{CBs}, x_{i j}$ constitutes the number of banks in country $i$ using correspondents in country $j$. For instance, if a bank in country A had correspondent relationship with ten banks in country B, $x_{i j}$ would equal ten. Thus, our measure of $\mathrm{CB}$ intends to capture the intensive 
margin of $\mathrm{CB}$ transactions. $\mathrm{Z}$ is a vector of bilateral indicators of the linkages between country pairs, as defined above.

In the case of MNBs we choose two alternative specifications, with $x_{i j}$ representing either the number of branches or the number of MNBs (with foreign branches) established by country $i$ in country $j$ in 1935.

After transforming equation (1) in log-linearized form and specifying the elements of vector $Z_{i j}$, we obtain:

$\ln \left(x_{i j}\right)=\ln \left(\alpha_{0}\right)+\alpha_{1} \ln \left(Y_{i}\right)+\alpha_{2} \ln \left(Y_{j}\right)+\beta_{1} \ln \left(T_{i j}\right)+\beta_{2} C O L_{i j}+\beta_{3} L A N_{i j}+\beta_{4} I F C+\beta_{5} \ln \left(D_{i j}\right)+$ $\beta_{6} \ln \left(R E M_{i}\right)+\beta_{7} E R_{i j}+\ln \left(e_{i j}\right)$

The cross-sectional data used for our baseline model are based on year 1935. Considering that the existence of cross-border banking connections is built up over a long time and displays a considerable degree of resilience, we also compute alternative specifications accounting for past economic variables. Specifically, in order to capture pre- and post-Great Depression economic trends, we substitute GDP per capita in 1935 with its values in 1928 and in 1930-34 (calculated as a five year average).

\section{Empirical challenges}

Two main challenges arise from the estimation of equation (2): first of all, the large presence of zeroes in the dependent variable, since most countries established a branch or a correspondent only in a limited number of countries. Ignoring these zeroes would mean losing a considerable number of observations, thus resulting in selection bias. We address this first challenge by estimating each gravity equation in its multiplicative form, using the Poisson pseudo-maximum likelihood (PPML) method, following Silva and Tenreyro. ${ }^{71}$ The PPML estimator has shown excellent performance when the data have many zeros, as proven 
by simulation evidence. ${ }^{72}$ Moreover, the PPML model works well also in case of over- and underdispersion, since it does not assume equidispersion.

A second concern stems from the potential endogeneity and reverse causality of bilateral trade. This is addressed using an instrumental-variable approach when performing the PPML regression. It is not easy to find a good instrument for trade which is not correlated with the spread of banks. ${ }^{73}$ Other studies adopting similar gravity specifications, using banking/financial data as a dependent variable, have used alternative measures to proxy trade, such as the host country's geographical latitude ${ }^{74}$ or transport costs. ${ }^{75}$ In the absence of available data on country-pair transport costs for the extensive geographic coverage of our historical dataset, we have created a 'relative factor endowment' instrument, drawing from trade theory. To this purpose we have classified $i$ and $j$ as labour, land or capital rich, based on a country's dominant economic sector and its role in global trade. For example, capitalrich core industrialising countries, mostly continental Europe and North America, which specialised in the production and export of capital intensive goods, were classified as capital abundant; on the other hand, the major producers and exporters of primary commodities, such as Australia, Argentina, India, Brazil, etc. were considered as land abundant. ${ }^{76}$ We have assigned a dummy of 1 if country pair relative factor endowments were similar and thus less likely to trade with each other and zero otherwise (see Appendix, Table A1). This instrument portrays a Heckscher-Ohlin type of world, in which a country's comparative advantage is determined by its relatively abundant factor of production. Thus, our instrumental variable (hereafter IV) intends to capture international trade patterns in 1935 as the manifestation of the world economic order during the 'great divergence', a period characterised by a widening gap between the industrial core, and a land/labour-rich poor periphery.

The validity of our instrument is conditional on it being correlated with the endogenous variable bilateral trade $\left(T_{i j}\right)$ and on impacting the dependent variable $\left(x_{i j}\right)$ indirectly via the 
instrumented variable $T_{i j}$. The first condition is confirmed by the results of the first stage regressions, which show highly statistically significant coefficients of the IV, in all specifications of both CBs and MNBs (see Tables 3 and 4, last row). The second condition holds since the IV embodies the likelihood of trade between two countries based on their relative factor endowments. While resource endowments per se may impact directly banks' numbers, our instrument is likely to have had an effect on $x_{i j}$ only via $T_{i j}$ and not directly.

\section{Results}

Table 5 identifies the various factors influencing international banking entry. We find that the location of the very large number of CBs, respondents and correspondents, is driven by bilateral trade flows and by whether the respondent or correspondent is domiciled in a country hosting an international financial centre. Specifically, a percentage increase in bilateral trade increases the possibility of using a foreign $\mathrm{CB}$ by 1.35 per cent on average; moreover, trading with a country with an IFC increases the likelihood of establishing a correspondent relationship by 15.42 per cent on average (columns I-III). ${ }^{77}$ Considering the magnitude of the coefficient, these findings are not only statistically but also economically significant. ${ }^{78}$ These results support our argument about the importance of trade underlying the volume and distribution of the payments system as well as the importance of financial centres as node points within that system. Two additional key variables are statistically significant GDP per capita of the host (in 1935 as well as pre and post 1935), and remoteness. The former suggests that partner's past and present economic size mattered. In fact, the significant coefficients on the host's GDP per capita mirrors the widespread use of CBs located in highincome countries, particularly Europe and North America. The latter points to the negative role of output weighted distance in using CBs, consistent with gravity equations.

The gravity model generates very different explanations of the location of MNBs and their branches. We find that home countries characteristics matter most. Namely countries hosting 
an international financial centre increased the average likelihood of establishing a MNB branch by 6.1 per cent (columns IV-VI) and a MNB bank by 3.53 per cent (columns VII-IX), across all specifications. Similarly, a percentage increase in home country GDP per capita made it more likely to open a MNB branch by 3.15 per cent and a MNB bank by 1.02 per cent. Both indicators are proxies for the sophistication of banks within a country's borders. Moreover, the pre-and post-Depression GDP per capita indicators have the same signs and significance as those in 1935, highlighting the resilience of the international financial architecture and the importance of past economic variables in determining the geography of global banking linkages.

Another key determinant for MNBs, but not CBs, is the presence of colonial linkages between countries. MNBs and their branches clustered disproportionally in 'safe' markets where they received implicit support from colonial administrations. The colony effect is very large: on average, having colonial ties increased the likelihood of opening an additional branch by 12 per cent (columns IV-VI) and of branching per se by 4.02 per cent (columns VII-IX). Indeed, the variable colonial linkages is likely to have captured not only the political/economic ties between the various metropoles and respective colonies, but also other institutional factors that may have facilitated MNBs expansion via lower entry costs resulting from common legal codes and political structures. ${ }^{79}$

To sum up, what differentiated the two modes of operation depended on several factors: the strength of current trade and colonial linkages, the economic size of the home and host countries (past and present) and the presence of international financial centres. Our analysis highlights that $\mathrm{CBs}$ followed trade networks and locations where risks associated with establishing MNBs were high, while MNBs offering financial intermediation preferred locating in 'safer' environments, as captured by the significance of the colonial dummy. 
MNBs also favoured operating in financial centres and having smaller exposure, in terms of assets deployed, by supporting home customers in only a few markets.

Overall, our findings reflect the predictions of transaction costs economics presented above and support the studies by Michie regarding the role of capital and securities markets in facilitating this web of payments. ${ }^{80}$

[Table 5 around here]

After checking the validity of our results via additional robustness tests, we explore further the potential reasons for these differences, focusing on the role of trade and colonial linkages.

\subsection{Robustness tests}

To assess the strengths of the empirical analysis we perform a series of robustness tests. First, we add an additional variable to the regressions, capturing the extent to which banking restrictions impacted cross border activities. Following Tschoegl, we add a dummy of 1 for countries whose governments prohibited or severely limited branching abroad or the entry of foreign banks. ${ }^{81}$ These were Norway, Finland, Sweden, Canada, Czechoslovakia, Hungary, the US and the USSR. We find that the results are robust to this addition and that banking restrictions impacted negatively the number of branches, but had no effect on CBs (columns I and II). Second, in order to account for the impact of high level trade restrictions characterising the interwar era, we include a measure of the level of protectionism for both home and host countries, following Clemens and Williamson. ${ }^{82}$ These variables are not significant and do not alter the validity of our results (columns III and IV). Thirdly, we drop from the sample all country pairs in which the host was a white settler economy (Australia, New Zealand and South Africa). ${ }^{83}$ Again, our main findings remain unchanged (columns V and VI). As a last robustness check, we test a key facet of international banking, fact that many banks both from core and peripheral economies branched into countries with large 
international financial centres to get direct access to their financial services and markets. To this purpose we added a dummy variable equal to one for hosts of IFC in the MNB specifications. We find that IFCs were a significant determinant for attracting a foreign MNB (column VIII), but not for adding an additional branch (column VII).

[Table 6 around here]

\section{Conclusion}

In this paper we have used material from the Bankers' Almanac to identify over 2000 commercial banks, as distinct from merchant banks, which were engaged in international banking in 1935 . However, the type of international banking services being offered differed greatly. The overwhelming majority of banks offered a single product: payments or collection services on behalf of their own customers that required the participation of a foreign bank, a correspondent. These inter-bank transaction were undertaken through arms' length contracting. We have argued that the nature of the product - its simplicity, the commonality of the documentation used in financing international trade, the rapid flow of information about the performance of correspondents - enabled the negotiating, writing and enforcement of an almost complete contract.

A much smaller number of banks opened branches abroad, and having done so also participated in correspondent relationships the provided payments services to their subsidiaries' customers. The motivation to become a multinational bank and to extend its geographic reach was in marked contrast to that faced by banks that entered only $\mathrm{CB}$ relationships. The FDI decision was framed by the banks' calculation of the prospective costs and revenues of operating in uncertain foreign markets by offering a bundle of both financial intermediation and payments products. However, an exception to this observation must be 
noted: foreign banks that opened branches in London seldom provided retail banking services rather confining themselves to wholesale markets. In either case it was an active calculation on the part of the MNB rather than a passive response in $\mathrm{CB}$ relationships.

The data presented in Tables 1 and 2 show the number of home based CBs, the number of CB with whom they had relations in foreign countries and the number of foreign banks (respondents) who used their services at both country and regional level. There are marked differences between countries in the number of their CBs, their reach abroad on behalf of their customers, and the services they provided to foreign banks. Not surprisingly, high income nations with relatively more advanced financial systems ${ }^{84}$, high GDP and extensive trade links lead the list in Table 1 of $\mathrm{CB}$ providers and users. Moreover, the attraction of international financial centres to foreign domiciled CBs, especially London and New York, was particularly strong. Our empirical testing using a gravity model finds strong support that the country distribution of CBs was driven by bilateral trade flows and by the correspondent's GDP per capita and its location in a financial centre.

We have argued that correspondent banking was an effective and widely used mode for handling the transfer of credits and debits within the international economy. While our data is drawn from the year 1935 we believe that the number and geographic pattern of CB relationships would hold broadly true for the inter-war period and possibly earlier. The spider's web of $\mathrm{CB}$ transactions was ideally suited to manage the vicissitudes of the economic shocks during WWI and between the wars. The system required little capital on the part of participants whose engagement depended on payments made or received by their customers. However, by the 1960s the character of international banking was undergoing great change. The combination of the emergence of offshore banking markets in USD, the relaxation of barriers to entry by foreign banks, the emergence of new international capital centres, especially in Asia, new technologies and a host of new financial products 
transformed MNBs. ${ }^{85}$ They became more numerous and very large, global banks. The old order of CBs was swept away to be replaced by new forms of international payments settlements. ${ }^{86}$ 


\section{REFERENCES}

Atkin, J., The Foreign Exchange Market of London: Development since 1900. Abingdon: Routledge, 2005.

Baster, A. S. J. The Imperial Banks. London: P. S. King \& Son, 1929. . The International Banks. London: P. S. King \& Sons, 1935. . "The international acceptance market", American Economic Review, 27, 2 (1937): 294-304.

Battilossi, S. "The determinants of multinational banking during the first globalisation 1880-1914." European Review of Economic History 10, no 3 (2006): 361-88.

Brealey, R. A. and E. Kaplanis, "The determination of foreign banking location." Journal of International Money and Finance, 15, no.4 (1996): 577-97.

Burk, H., Morgan Grenfell 1838-1988: The Biography of a Merchant Bank. Oxford: Oxford University Press, 1989.

Butlin, N. G., Australian Domestic Product, Investment and Foreign Borrowing 1861-1938/39. Cambridge at the University Press, 1962.

Butlin, S. J., Australia and New Zealand Bank,: The Bank of Australasia and the Union Bank of Australia Limited 1828-1951, London: Longmans, 1961.

Butlin, S. J., A. R. Hall and R. C. White, Australian Banking and Monetary Statistics 1817-1945, Occasional Paper No. 4A, Sydney: Reserve Bank of Australia.

Cameron, R., O. Crisp, H. T. Patrick and R. Tilly, Banking in the Early Stages of Industrialization. New York: Oxford University Press, 1967

Cameron, R. and V. I. Bovykin, Eds., International Banking, 1870-1914. New York and Oxford: Oxford University Press, 1991.

Cassis, Y., Capitals of Capital: The Rise and Fall of International Financial Centres, 1780-2009. Cambridge: Cambridge University Press, 2010.

Casson, M., "Evolution of multinational banks: a theoretical perspective", in G. Jones, ed., Banks as Multinationals. Routledge: New York, 1990: 14-29. 
Channon, D. F., Global Banking Strategy, New York: John Wiley \& Sons, 1988.

Chapman, S., The Rise of Merchant Banking. London: George Allen \& Unwin, 1985.

Chitu, L., B. Eichengreen, and A. Mehl, "History, gravity and international finance". Journal of International Money and Finance, 46 (2014): 104-29.

Clemens, M.A and J. G. Williamson, "Why did the tariff-growth correlation change after 1950?" Journal of Economic Growth 9, no 1 (2004): 5-46.

Chernow, R., The House of Morgan: An American Banking Dynasty and the Rise of Modern Finance. New York, A Touchstone Book, 1990.

The Warburgs: A Family Saga. London, Pimlico, 1993.

Commonwealth Bureau of Census and Statistics, Trade and Customs and Excise Revenue of the Commonwealth of Australia 1910, Table XIII, Melbourne.

Overseas Trade Bulletin No.33, 1935-36, Table X, Canberra.

Collins, M., Money and Banking in the UK: A History, London: Croom Helm, 1988.

Cottrell, P.L., E. Lange, E. and U. Olson, eds., Centres and Peripheries in Banking: The Historical Development of Financial Markets. Aldershot: Ashgate, 2007: 41-79.

Dunn, R. W., American Foreign Investments. New York: B. W. Huebsch and the Viking Press, 1926.

Dunning, J. H., and S. M. Lundan, Multinational Enterprises and the Global Economy. Cheltenham, UK and Northampton, MA, USA: Edward Elgar Publishing, $2^{\text {nd }}$ ed., 2008.

Easton, H. T., "The growth of banking facilities", The Economic Journal, 11, no 42 (1901): 244-51.

Eichengreen, B. J., Globalising Capital: A History of the International Monetary System. Princeton, NJ: Princeton University Press, $2^{\text {nd }}$ ed., 2008

Eichengreen, B. J. and D. A. Irwin, “The slide to protectionism in the Great Depression: Who succumbed and why?" The Journal of Economic History, 70 no 4 (2010): 871-897.

Ellis, A., Heir to Adventure: The Story of Brown, Shipley \& Co. Merchant Bankers. Issued privately.

Esperanca, J. P. and M. A. Gulambusse, "(Re)testing the 'follow the customer' hypothesis in multinational bank expansion”, Journal of Multinational Financial Management, 11 (2001): 281-93.

Feenstra, R., Markusen J., \& Rose A., "Using the gravity equation to differentiate among alternative theories of trade," Canadian Journal of Economics, 34, no 2 (2001): 430-447. 
Ferguson, N., The House of Rothschild. New York: Viking, 2 vols, 1998.

High Financier: The Lives and Times of Siegmund Warburg. London: Allen Lane, 2010.

Giblin, L. F, The Growth of a Central Bank: The Development of The Commonwealth Bank of Australia 1926-1945, Melbourne: Melbourne University Press.

Goldsmith, R. W., Financial Structure and Development. New Haven and London: Yale University Press, 1969.

The Financial Development of Japan, 1868-1977. New Haven and London: Yale University Press, 1983.

Hejazi, W., "Reconsidering the concentration of US MNE activity: Is it global, regional or national?", Management International Review, 4, no 1 (1994): 5-27.

Hawtrey, R. G., Currency and Credit, London: Longmans, Green and Co, 1930.

Heurtas, T. F., "US multinational banking: History and prospects", in Jones, g., ed., Bank as Multinationals, London and New York: Routledge, 1990, 248-67.

Holder, R. F., Bank of New South Wales: A History, Sydney: Angus and Robertson, 1970, 2 volumes.

Holmes, A. R. and E. Green, Midland: 150 Years of Banking Business, London: B. T. Batsford.

Howe, A. C. "Palgrave, Sir (Robert Harry) Inglis (1827-1919)", Oxford Dictionary of National Biography, Oxford University Press, 2004; online edn, Jan 2008

James, J. A. and Weiman, D. F., "From drafts to checks: the evolution of correspondnent banking networks and the formation of the modern U. S. payments system, 1850-1914", Journal of Money, Credit and Banking, 42, 2/3, 2010, 237-65.

Jones, G. ed., "Competitive advantages in British multinational banking since 1890" in G. Jones, ed., Banks as Multinationals. London and New York: Routledge, 1990: 30-61. British Multinational Banking 1830-1990. Oxford: Oxford University Press, 1993. "British multinational banking in Asia before 1960: Lending strategies and human resource management", in Checkland, O., S. Nishimura and N. Tamaki, eds., Pacific Banking 1859-1959, East Meets West. London: Macmillan Press, 1994: 151-68. 
"British overseas banks as free-standing companies 1830-1996", in Wilkins, M. and Schröter, H., eds., The Free-Standing Company in the World Economy 1830-1996, Oxford: Oxford University Press, 1998: 344-60.

Lawrence, R. J. and D. Lougee, "Determinants of correspondent banking relationships", Journal of Money, Credit and Banking, 2, 3 (1970): 358-69. Merchants to Multinationals: British Trading Companies in the Nineteenth and Twentieth Centuries. Oxford: Oxford University Press, 2000.

Khoury, S. J., The Deregulation of the World Financial Markets: Myths, Realities and Impact, London: Printer Publishers, 1990.

le Cheminant, K., Colonial and Foreign Banking Systems. London: George Routledge \& Sons, 1924.

Lescure, M. 2008. 'Banking and finance' in Geoffrey Jones and Jonathon Zeitin, eds, The Oxford Handbook of Business History. Oxford: Oxford University Press, pp. 319-46.

League of Nations, Commercial Banks. Geneva, various editions. The network of world trade. Geneva, 1942.

Magee, G. B. and A. S. Thompson, Empire and Globalisation: Networks of People, Goods and Capital in the British World, c. 1850-1914. Cambridge: Cambridge University Press, 2010.

McCloskey, D. and S. Ziliak,. "The standard error of regressions". Journal of Economic Literature 34, (1996) 97-114.

Melitz, M., "North, South and Distance in the gravity equation”, European Economic Review, 51 (2007): 971-991.

Meltzer, Allan H. "Monetary and other explanations of the start of the Great Depression." Journal of Monetary Economics 2, no. 4 (1976): 455-471.

Merrett, D. T., “Australian banks and Asia: Opportunities foregone or rational management? An industrial organizations approach", in Checkland, O., Nishimura S. and Tamaki, N., eds., Pacific Banking, 1859-1959: East Meets West, Basingstoke: Macmillan, 1984: 169-84. . "Global reach by Australian banks: correspondent banking networks, 1830-1960”, Business History, 37 no 3 (1995): 70-88. 
Michie, R. "Banks and securities markets 1870-1914," in Forsyth, D. J. and D. Verdier, eds., The Origins of National Financial Systems: Alexander Gerschenkron Reconsidered: London: Routledge, 2003: $41-63$

"The City of London as a global financial centre, 1880-1939: finance, foreign exchange, and the First World War" in Cottrell, P.L., E. Lange, E. and U. Olson, eds., Centres and Peripheries in Banking: The Historical Development of Financial Markets. Aldershot: Ashgate, 2007: 41-79.

"The City of London as a Centre for International Banking: The Asian Dimension in the Nineteenth and Twentieth century", in Nishimura, S., T. Suzuki and R. Michie, eds., The Origins of International Banking in Asia: The Nineteenth and Twentieth Centuries. Oxford: Oxford University Press, 2012: 13-54.

Mollan, S., "International correspondent networks: Asian and British banks in the twentieth century" in Nishimura, S., T. Suzuki and R. Michie, eds., The Origins of International Banking in Asia: The Nineteenth and Twentieth Centuries. Oxford: Oxford University Press, 2012: 217-29.

Moore, B. A. and Barton A. S., Banking in New Zealand, Wellington: New Zealand Bank Officers' Guild, 1935.

Mitchell, B. R. International Historical Statistics [electronic resource]/edited by Palgrave Macmillan Ltd, 2013.

Naughton, T. and L. S-L. Chan, "Strategic dimensions of correspondent banking", International Journal of Bank Marketing, 16 no 4 (1998): 153-60.

Nishimura, S., "The flow of funds with the Hong Kong and Shanghai Banking Corporation in 1913", in O. Checkland, S. Nishimura and N. Tamaki, Pacific Banking, 1859-1959: East Meets West, Basingstoke: Macmillan, 24-51.

Osterberg, W. P., and Thomson, J. B., "Banking consolidation and correspondent banking", Economic Review, Q1 (1999): 9-20

Papaioannou, E. "What drives international bank flows? Politics, institutions and other determinant", ECB Working Paper Series, no. 437, 2005.

Portes, R., H. Rey, H. and Y. Oh, "Information and capital flows: the determinants of transactions in financial assets", European Economic Review 45 (2001): 783-796. 
Pratt, J. W. and R. J. Zeckhauser, eds., Principals and Agents: The Structure of Business, Boston, MA: Harvard Business School Press, 1985: 1-35

Reed, H. C., The Preeminence of International Financial Centres. New York: Praeger Publishers, 1981.

Roberts, R., Schroders: Merchants \& Bankers. Basingstock and London, Macmillan, 1992.

Rustici, Thomas. "Banking Crises and the Great Depression" in eds. T. Rustici, J. Caton, D. Shamoun and T. Shamoun, Macroeconomics: Past and Present, Volume 2 (2015), Cognella Editors, pp. 143175.

Skinner, T., The Bankers' Almanac and Year Book 1936-37. London: Thomas Skinner \& Co, 1937.

Silva, J. M. C. Santos, and Silvana Tenreyro, "Further simulation evidence on the performance of the Poisson pseudo-maximum likelihood estimator", Economics Letters, 112, no.2 (2011): 220-222.

'The log of gravity', Review of Economics and Statistics 88, no.4 (2006): 641-658.

Tschoegl, A. E., "Ideology and changes in regulations: The case of foreign bank branches over the period 1920-80", in T. L. Brewer, ed., Political Risks in International Business: New Directions for Research, Management and Public Policy. New York: Praeger, 1985, 95-114.

"International retail banking as a strategy: An assessment", Journal of International Business Studies, 19, no 2 (1987): 67-88.

Union Bank of Australia, “Melbourne Branch Sub-Inspector's Report, 27 June 1921 to 16 December 1921”, ANZ Bank Archive, U/93/24 (1921).

Verdier, D., Moving Money: Banking and Finance in the Industrialised World, Cambridge: Cambridge University Press, 2002.

Ville, S., "The relocation of the international market for Australian wool", Australian Economic History Review, 45, 1, 2005, 73-95.

Wilkins, M. The Maturing of Multinational Enterprise: American Business Abroad from 1914 to 1970 , Cambridge, MA: Harvard University Press, 1974.

The History of Foreign Investment in the United States, 1914-1945, Cambridge, MA: Harvard University Press, 2004.

Williams, B., "The defensive expansion approach to multinational banking: evidence to date", Financial Markets, Institutions \& Instruments 1, no 2 (2002): 127-203. 
Williamson, J. G., "Land, labor, and globalization in the third world, 1870-1940", Journal of Economic History 62, no 1 (2002): 55-85.

Williamson, O. E., The Economic Institutions of Capitalism: Firms, Markets, Relational Contracts, New York: Free Press, 1985,

Wood, R. J., The Commercial Bank of Australia Limited: History of an Australian institution 1866-1981, North Melbourne: Hargreen Publishing Company, 1990.

Ziegler, P., The Sixth Power: Barings, 1762-1929, London, Collins, 1988. 
Tables

Table 1: Correspondent and multinational banks by country in 1935 .

\begin{tabular}{|c|c|c|c|c|}
\hline Country & $\begin{array}{c}\text { Home } \\
\text { based } \\
\text { CBs }\end{array}$ & $\begin{array}{c}\text { Foreign CBs } \\
\text { used }\end{array}$ & $\begin{array}{c}\text { Foreign banks } \\
\text { using } \\
\text { country's CBs }\end{array}$ & MNBS \\
\hline Germany & 251 & 515 & 36 & 5 \\
\hline US & 238 & 324 & 1427 & 6 \\
\hline France & 151 & 338 & 133 & 30 \\
\hline Switzerland & 148 & 313 & 155 & 1 \\
\hline Holland & 125 & 286 & 26 & 4 \\
\hline Denmark & 85 & 179 & 12 & 1 \\
\hline Italy & 80 & 140 & 106 & 7 \\
\hline UK & 71 & 145 & 1748 & 24 \\
\hline Belgium & 67 & 150 & 76 & 7 \\
\hline Norway & 66 & 128 & 12 & \\
\hline Spain & 64 & 146 & 20 & 3 \\
\hline Poland & 51 & 121 & 6 & 2 \\
\hline Yugoslavia & 35 & 88 & 4 & 1 \\
\hline Austria & 34 & 79 & 14 & 1 \\
\hline Rumania & 30 & 78 & 3 & \\
\hline Portugal & 28 & 68 & 13 & 1 \\
\hline Sweden & 28 & 70 & 15 & \\
\hline Hungary & 27 & 59 & 4 & \\
\hline Czechoslovakia & 26 & 56 & 10 & 2 \\
\hline Brazil & 22 & 89 & 5 & \\
\hline Greece & 19 & 36 & 10 & 2 \\
\hline Argentina & 17 & 32 & 5 & 3 \\
\hline India & 17 & 23 & 10 & 1 \\
\hline China & 16 & 34 & 14 & 2 \\
\hline Canada & 15 & 64 & 49 & 7 \\
\hline Finland & 15 & 35 & 6 & \\
\hline Colombia & 13 & 19 & 3 & 1 \\
\hline Japan & 13 & 30 & 8 & 3 \\
\hline Lithuania & 13 & 26 & 1 & \\
\hline Egypt & 11 & 27 & 5 & 2 \\
\hline Latvia & 11 & 21 & 2 & \\
\hline Venezuela & 10 & 26 & 1 & \\
\hline Australia & 9 & 34 & 13 & 6 \\
\hline Bulgaria & 9 & 48 & 3 & \\
\hline Estonia & 9 & 30 & 1 & \\
\hline Chile & 8 & 14 & 7 & 1 \\
\hline Mexico & 8 & 20 & 4 & 1 \\
\hline Ecuador & 7 & 14 & 2 & \\
\hline Turkey & 7 & 15 & 8 & 2 \\
\hline Uruguay & 6 & 15 & 4 & 1 \\
\hline Jamaica & 5 & 3 & 1 & 1 \\
\hline Philippines & 5 & 10 & 0 & 1 \\
\hline Costa Rica & 4 & 6 & 0 & \\
\hline Ireland & 4 & 5 & 4 & \\
\hline Peru & 4 & 11 & 3 & \\
\hline Bolivia & 3 & 6 & 2 & \\
\hline El Salvador & 3 & 6 & 1 & \\
\hline Guatemala & 3 & 4 & 1 & \\
\hline
\end{tabular}




\begin{tabular}{lcccc}
\hline Malaya & 3 & 1 & 1 & 1 \\
USSR & 3 & 6 & 3 & \\
Ceylon & 2 & 2 & 2 & 2 \\
Cuba & 2 & 4 & 1 & 1 \\
Indonesia & 2 & 5 & 1 & \\
Nicaragua & 2 & 4 & 1 & \\
New Zealand & 2 & 5 & 4 & 133 \\
Union of South Africa & 2 & 4 & 10 & \\
French West Africa & 1 & 1 & 0 & \\
\hline Total & 1910 & 4018 & 4016 & \\
\hline
\end{tabular}

Source: Skinner, The Bankers' Almanac. 
Table 2: Banks providing and using CBs and MNBs by region, 1935

\begin{tabular}{|c|c|c|c|c|c|c|c|c|}
\hline & \multicolumn{2}{|c|}{$\begin{array}{l}\text { Banks using } \\
\text { correspondents }\end{array}$} & \multicolumn{2}{|c|}{ Correspondents } & \multicolumn{2}{|c|}{$M N B$} & \multicolumn{2}{|c|}{ MNB branches (\%) } \\
\hline & Number & $(\%)$ & $\begin{array}{l}\text { Use of } \\
\text { world } \\
\text { CB (\%) }\end{array}$ & $\begin{array}{l}\text { Host to } \\
\text { world } \\
\text { CBs (\%) }\end{array}$ & Number & $(\%)$ & Outbound & Inbound \\
\hline Region & I & II & III & IV & $\mathrm{V}$ & VI & VII & VIII \\
\hline Africa & 14 & $<1$ & $<1$ & $<1$ & 2 & 1.5 & $<1$ & 39 \\
\hline $\begin{array}{l}\text { North } \\
\text { America }\end{array}$ & 253 & 13 & 10 & 37 & 13 & 10 & 6 & 1 \\
\hline Latin & & & & & & & & \\
\hline America & 117 & 6 & 7 & 1 & 8 & 6 & $<1$ & 7 \\
\hline Asia & 61 & 3 & 3 & $<1$ & 9 & 7 & 5 & 13 \\
\hline USSR & 3 & $<1$ & $<1$ & $<1$ & 1 & $<1$ & $<1$ & 0 \\
\hline Europe & 1454 & 76 & 79 & 60 & 93 & 70 & 85 & 10 \\
\hline Oceania & 11 & $<1$ & $<1$ & $<1$ & 7 & 5 & 3.5 & 30 \\
\hline World & 1910 & 100 & 100 & 100 & 133 & 100 & 100 & 100 \\
\hline
\end{tabular}

Note: Outbound branches represent the share of all MNB branches from each region situated in foreign countries. Inbound branches refer to the share of foreign MNBs branches within each region. Banks within each region may have correspondents in other countries within the region. This intra-region presence is particularly the case in Europe.

Source: Skinner, The Bankers' Almanac. 
Table 3: Drivers of international settlements by region, 1935 (\$USm)

\begin{tabular}{lccccc}
\hline Region & Exports & $\begin{array}{c}\text { Stock outward } \\
\text { FDI }\end{array}$ & Imports & $\begin{array}{c}\text { Stock inward } \\
\text { FDI }\end{array}$ & $\begin{array}{c}\text { Foreign owned } \\
\text { public debt }\end{array}$ \\
\hline Africa & 1276 & 0 & 1113 & 1799 & 1252 \\
North America & 2593 & 8000 & 3215 & 4096 & 833 \\
Latin America & 1328 & 0 & 1975 & 7481 & 2541 \\
Asia & 2651 & 750 & 3421 & 6689 & 2351 \\
Europe & 10792 & 17380 & 10330 & 2200 & 23302 \\
Oceania & 490 & 300 & 751 & 1950 & 2962 \\
World & 19076 & 26350 & 20805 & 24315 & 33241 \\
\hline Notes:
\end{tabular}

Notes: The regions are those defined in the League of Nations (1942), Annex III, 106-7. We have included the USSR with Europe.

Sources: Columns two and four (exports and imports) from League of Nations (1942), Annex III, 171. Columns three and five (stocks of outward and inward FDI) from Dunning and Lundan (2008), Tables 6.1 and 6.2, 174-5. Column six (foreign debt outstanding) from League of Nations (1937), Table 136, 'Public Finance, Public Debt and Debt Service', 293-303. 
Table 4: Trade partners, mean value of trade and percentage of partners with trade balance of $\$ 3 \mathrm{~m}$ or less by region, 1935.

\begin{tabular}{lcccc}
\hline Region & $\begin{array}{c}\text { No. } \\
\text { countries }\end{array}$ & $\begin{array}{c}\text { No. trade } \\
\text { partners }\end{array}$ & $\begin{array}{c}\text { Mean trade } \\
\text { value } \$ m^{*}\end{array}$ & $\begin{array}{c}\text { \% of countries } \\
\text { with bilateral } \\
\text { trade } \leq \$ 3 m\end{array}$ \\
\hline \multicolumn{1}{c}{ I } & II & III & IV \\
North & 3 & 65 & $12.46(4.04)$ & 50.77 \\
America & 2 & 93 & $57.90(12.42)$ & 18.28 \\
Latin & 16 & 245 & $10.46(1.69)$ & 57.14 \\
America & & & & \\
Asia & 7 & 194 & $21.97(3.81)$ & 47.94 \\
Europe & 27 & 872 & $22.39(1.67)$ & 39.68 \\
Oceania & 2 & 49 & $23.10(9.25)$ & 51.02 \\
Total & 57 & 1518 & $22.18(1.41)$ & 43.08 \\
\hline
\end{tabular}

Note: * standard deviation in parenthesis.

Sources: Skinner The Bankers' Almanac. League of Nations (Network, Annex III, 112-71). 
Table 5: Baseline regressions results

\begin{tabular}{|c|c|c|c|c|c|c|c|c|c|}
\hline & \multicolumn{3}{|c|}{ Correspondents } & \multicolumn{3}{|c|}{ MNB branches } & \multicolumn{3}{|c|}{ MNB banks } \\
\hline & (I) & (II) & (III) & (IV) & (V) & (VI) & (VII) & (VIII) & (IX) \\
\hline \multirow[t]{2}{*}{ Trade } & $0.932^{* *}$ & $0.873^{* * *}$ & $0.751^{*}$ & 0.004 & 0.005 & 0.006 & 0.004 & -0.000 & -0.000 \\
\hline & $(0.295)$ & $(0.200)$ & $(0.202)$ & $(0.005)$ & $(0.005)$ & $(0.005)$ & $(0.002)$ & $(0.001)$ & $(0.001)$ \\
\hline \multirow[t]{2}{*}{ Colony } & -1.142 & 1.111 & 0.557 & $2.658^{* * *}$ & $2.621^{* * *}$ & $2.397^{* * *}$ & $1.092^{* *}$ & $1.983^{* *}$ & $1.576^{* * *}$ \\
\hline & $(0.551)$ & $(0.593)$ & $(0.491)$ & $(0.821)$ & $(0.671)$ & $(0.675)$ & $(0.465)$ & $(0.296)$ & $(0.326)$ \\
\hline \multirow[t]{2}{*}{ Language } & -0.298 & -0.709 & $-1.534^{* * * *}$ & 0.715 & 0.681 & 0.662 & $0.689^{* * *}$ & 1.158 & $0.635^{* * *}$ \\
\hline & $(0.551)$ & $(0.564)$ & $(0.548)$ & $(0.580)$ & $(0.560)$ & $(0.591)$ & $(0.645)$ & $(0.657)$ & $(0.232)$ \\
\hline Financial & $2.825^{* * *}$ & $2.305^{* * *}$ & $3.108^{* * * *}$ & $1.972^{* * *}$ & $2.000^{* * *}$ & $1.908^{* * *}$ & $1.673^{* * * *}$ & $1.377^{* * *}$ & $1.458^{* * *}$ \\
\hline center & $(0.175)$ & $(0.135)$ & $(0.219)$ & $(0.311)$ & $(0.408)$ & $(0.385)$ & $(0.169)$ & $(0.185)$ & $(0.204)$ \\
\hline GDPpc & -0.278 & & & $1.424^{* *}$ & & & $0.702^{* * *}$ & & \\
\hline (home) & $(0.186)$ & & & $(0.541)$ & & & (0.199) & & \\
\hline GDPpc & $2.209^{* * *}$ & & & 0.438 & & & -0.003 & & \\
\hline (partner) & $(0.296)$ & & & $(0.434)$ & & & $(0.175)$ & & \\
\hline \multirow[t]{2}{*}{ Distance } & 0.205 & -0.188 & 0.072 & -0.074 & -0.059 & -0.042 & $-0.277^{* *}$ & $-0.314^{* * *}$ & $-0.338^{* * *}$ \\
\hline & $(0.138)$ & $(0.127)$ & $(0.110)$ & $(0.1033)$ & $(0.171)$ & $(0.172)$ & $(0.094)$ & $(0.088)$ & $(0.095)$ \\
\hline Remote- & $-4.047^{* * *}$ & $-3.395^{* * *}$ & $-1.481^{* * *}$ & -0.793 & -1.219 & -1.074 & -0.723 & -0.455 & -0.835 \\
\hline Ness & $(0.697)$ & $(0.657)$ & $(0.505)$ & $(1.033)$ & $(0.121)$ & $(1.210)$ & (1.496) & $(1.282)$ & $(0.749)$ \\
\hline Exchange & -0.359 & 0.125 & 0.127 & $0.668 *$ & $0.774 * *$ & $0.686^{*}$ & -0.148 & 0.145 & -0.012 \\
\hline Rate & $(0.427)$ & $(0.257)$ & $(0.654)$ & $(0.374)$ & $(0.378)$ & $(0.372)$ & $(0.257)$ & $(0.222)$ & $(0.211)$ \\
\hline GDPpc28 & & -0.061 & & & $1.038^{*}$ & & & $0.877^{* * *}$ & \\
\hline (home) & & $(0.108)$ & & & $(0.578)$ & & & $(0.222)$ & \\
\hline GDPpc28 & & $2.063^{* * *}$ & & & 0.391 & & & $0.339^{* *}$ & \\
\hline (partner) & & $(0.266)$ & & & $(0.513)$ & & & $(0.137)$ & \\
\hline GDPpc31-4 & & & 0.378 & & & $1.293^{* *}$ & & & $0.836^{* * *}$ \\
\hline (home) & & & $(0.307)$ & & & $(0.611)$ & & & $(0.277)$ \\
\hline GDPpc31-4 & & & $5.643^{* * *}$ & & & 0.226 & & & $0.225^{*}$ \\
\hline (partner) & & & $(0.497)$ & & & $(0.523)$ & & & $(0.124)$ \\
\hline \multicolumn{10}{|l|}{ Fixed } \\
\hline effects & Y & $\mathrm{Y}$ & $\mathrm{Y}$ & $\mathrm{Y}$ & $\mathrm{Y}$ & Y & Y & Y & Y \\
\hline $\mathrm{N}$ & 2609 & 2609 & 2609 & 2609 & 2609 & 2609 & 2609 & 2609 & 2609 \\
\hline Pseudo $\mathrm{R}^{2}$ & 0.21 & 0.45 & 0.63 & 0.60 & 0.58 & 0.45 & 0.26 & 0.42 & 0.39 \\
\hline First stage & \multicolumn{9}{|c|}{ Dependent variable: trade } \\
\hline Factor & $-0.206^{* * *}$ & $-0.025^{* * *}$ & $-0.026^{* * *}$ & $-0.11^{* * * *}$ & $-0.016^{* * *}$ & $-0.017^{* * *}$ & $-0.11^{* * *}$ & $-0.016^{* * *}$ & $-0.017^{* * *}$ \\
\hline Endowm. & $(0.013)$ & $(0.006)$ & $(0.006)$ & $(0.013)$ & $(0.005)$ & $(0.006)$ & $(0.013)$ & $(0.005)$ & $(0.006)$ \\
\hline
\end{tabular}

Note. Estimation by two stage pseudo maximum likelihood Poisson regression, with regional fixed effects. Bootstrapped standard errors, clustered by country pairs in parenthesis. Significance level at $1 \%\left(^{* * *}\right), 5 \%\left(^{* *}\right)$ and $10 \%\left(^{*}\right)$. 
Table 6: Robustness tests

\begin{tabular}{|c|c|c|c|c|c|c|c|c|}
\hline & \multicolumn{2}{|c|}{ Banks restrictions } & \multicolumn{2}{|c|}{ Trade barriers } & \multicolumn{2}{|c|}{ Without settlers } & \multicolumn{2}{|c|}{ IFC host } \\
\hline & CBs & $\begin{array}{l}\text { MNB } \\
\text { branch }\end{array}$ & CBs & $\begin{array}{l}\text { MNB } \\
\text { branch }\end{array}$ & $\begin{array}{l}\text { MNB } \\
\text { branch }\end{array}$ & $\begin{array}{l}\text { MNB } \\
\text { banks }\end{array}$ & $\begin{array}{l}\text { MNB } \\
\text { branch }\end{array}$ & $\begin{array}{l}\text { MNB } \\
\text { banks }\end{array}$ \\
\hline & (I) & (II) & (III) & (IV) & $(\mathrm{V})$ & (VI) & (VII) & (VIII) \\
\hline Trade & $\begin{array}{l}0.911^{* *} \\
(0.206)\end{array}$ & $\begin{array}{c}0.004 \\
(0.005)\end{array}$ & $\begin{array}{l}0.805^{* *} \\
(0.202)\end{array}$ & $\begin{array}{c}0.004 \\
(0.004)\end{array}$ & $\begin{array}{c}0.005 \\
(0.005)\end{array}$ & $\begin{array}{c}0.006 \\
(0.004)\end{array}$ & $\begin{array}{c}0.004 \\
(0.005)\end{array}$ & $\begin{array}{c}0.004 \\
(0.004)\end{array}$ \\
\hline Colony & $\begin{array}{l}-1.206 \\
(1.373)\end{array}$ & $\begin{array}{c}2.019^{* * *} \\
(0.784)\end{array}$ & $\begin{array}{l}-0.816 \\
(0.710)\end{array}$ & $\begin{array}{l}1.663^{* *} \\
(0.757)\end{array}$ & $\begin{array}{c}1.525^{*} \\
(0.898)\end{array}$ & $\begin{array}{c}0.380^{*} \\
(0.230)\end{array}$ & $\begin{array}{l}2.697^{* *} \\
(0.868)\end{array}$ & $\begin{array}{l}1.306^{* * * *} \\
(0.360)\end{array}$ \\
\hline Language & $\begin{array}{l}-0.579 \\
(0.783)\end{array}$ & $\begin{array}{c}0.578 \\
(0.515)\end{array}$ & $\begin{array}{c}0.157 \\
(0.800)\end{array}$ & $\begin{array}{c}0.328 \\
(0.537)\end{array}$ & $\begin{array}{c}0.477 \\
(0.527)\end{array}$ & $\begin{array}{c}0.760 * * \\
(0.308)\end{array}$ & $\begin{array}{c}0.712 \\
(0.571)\end{array}$ & $\begin{array}{l}0.683^{* *} \\
(0.248)\end{array}$ \\
\hline $\begin{array}{l}\text { Financial } \\
\text { centre }\end{array}$ & $\begin{array}{c}3.450^{* * * *} \\
(0.191)\end{array}$ & $\begin{array}{c}2.140^{* * *} \\
(0.305)\end{array}$ & $\begin{array}{l}2.694^{* * * *} \\
(0.306)\end{array}$ & $\begin{array}{l}1.460^{* * * *} \\
(0.538)\end{array}$ & $\begin{array}{c}2.313^{* * *} \\
(0.268)\end{array}$ & $\begin{array}{l}1.686^{* * *} \\
(0.152)\end{array}$ & $\begin{array}{c}2.122^{* * *} \\
(0.508)\end{array}$ & $\begin{array}{l}0.662^{* *} \\
(0.223)\end{array}$ \\
\hline Distance & $\begin{array}{c}0.294^{*} \\
(0.155)\end{array}$ & $\begin{array}{l}-0.056 \\
(0.168)\end{array}$ & $\begin{array}{c}0.042 \\
(0.170)\end{array}$ & $\begin{array}{l}-0.196 \\
(0.258)\end{array}$ & $\begin{array}{c}-0.214 \\
(0.185)\end{array}$ & $\begin{array}{c}-0.156 \\
(0.100)\end{array}$ & $\begin{array}{l}-0.084 \\
(0.198)\end{array}$ & $\begin{array}{c}-0.318^{* * * *} \\
(0.088)\end{array}$ \\
\hline $\begin{array}{l}\text { Remote- } \\
\text { ness }\end{array}$ & $\begin{array}{c}-4.624^{* * *} \\
(0.611)\end{array}$ & $\begin{array}{l}-0.079 \\
(0.997)\end{array}$ & $\begin{array}{c}-4.232^{* * *} \\
(0.790)\end{array}$ & $\begin{array}{c}0.103 \\
(1.076)\end{array}$ & $\begin{array}{c}-0.718 \\
(0.599)\end{array}$ & $\begin{array}{c}-0.374 \\
(1.490)\end{array}$ & $\begin{array}{l}-0.760 \\
(1.138)\end{array}$ & $\begin{array}{c}-0.762 \\
(1.430)\end{array}$ \\
\hline $\begin{array}{l}\text { Exchange } \\
\text { rate }\end{array}$ & $\begin{array}{l}-0.467 \\
(0.556)\end{array}$ & $\begin{array}{c}0.638^{*} \\
(0.355)\end{array}$ & $\begin{array}{l}-0.751 \\
(0.520)\end{array}$ & $\begin{array}{l}0.599 * \\
(0.353)\end{array}$ & $\begin{array}{c}0.234 \\
(0.455)\end{array}$ & $\begin{array}{c}-0.143 \\
(0.271)\end{array}$ & $\begin{array}{c}0.662^{*} \\
(0.362)\end{array}$ & $\begin{array}{c}0.030 \\
(0.164)\end{array}$ \\
\hline $\begin{array}{l}\text { GDPpc } \\
\text { (home) }\end{array}$ & $\begin{array}{c}-0.243 \\
(0.148)\end{array}$ & $\begin{array}{l}1.521^{* * *} \\
(0.426)\end{array}$ & $\begin{array}{c}-0.619^{* * * *} \\
(0.167)\end{array}$ & $\begin{array}{l}1.351^{* *} \\
(0.585)\end{array}$ & $\begin{array}{c}0.795^{* * *} \\
(0.239)\end{array}$ & $\begin{array}{c}0.659^{* * *} \\
(0.204)\end{array}$ & $\begin{array}{l}1.422^{* *} \\
(0.543)\end{array}$ & $\begin{array}{c}0.708^{* * *} \\
(0.208)\end{array}$ \\
\hline $\begin{array}{l}\text { GDPpc } \\
\text { (partner) }\end{array}$ & $\begin{array}{l}2.320^{* * * *} \\
(0.322)\end{array}$ & $\begin{array}{c}0.069 \\
(0.318)\end{array}$ & $\begin{array}{l}2.284^{* * * *} \\
(0.432)\end{array}$ & $\begin{array}{l}-0.142 \\
(0.315)\end{array}$ & $\begin{array}{l}-0.342 \\
(0.286)\end{array}$ & $\begin{array}{c}0.064 \\
(0.208)\end{array}$ & $\begin{array}{c}0.449 \\
(0.464)\end{array}$ & $\begin{array}{c}0.021 \\
(0.143)\end{array}$ \\
\hline $\begin{array}{l}\text { Bank } \\
\text { restrict }\end{array}$ & $\begin{array}{c}0.007 \\
(0.432)\end{array}$ & $\begin{array}{c}-1.360^{* * *} \\
(0.710)\end{array}$ & $\begin{array}{c}0.717 \\
(0.503)\end{array}$ & $\begin{array}{l}-1.145^{*} \\
(0.666)\end{array}$ & & & & \\
\hline $\begin{array}{l}\text { Protection } \\
\text { (home) } \\
\text { Protection } \\
\text { (partner) }\end{array}$ & & & $\begin{array}{c}-2.271 \\
(2.102) \\
2.421 \\
(1.751)\end{array}$ & $\begin{array}{c}1.428 \\
(3.153) \\
1.123 \\
(0.755)\end{array}$ & & & & \\
\hline $\begin{array}{l}\text { IFC } \\
\text { (host) }\end{array}$ & & & & & & & $\begin{array}{l}-0.217 \\
(0.839)\end{array}$ & $\begin{array}{l}1.367^{* * *} \\
(0.241)\end{array}$ \\
\hline $\begin{array}{l}\text { Fixed } \\
\text { Effects }\end{array}$ & $\mathrm{Y}$ & $\mathrm{Y}$ & $\mathrm{Y}$ & $\mathrm{Y}$ & $\mathrm{Y}$ & $\mathrm{Y}$ & $\mathrm{Y}$ & $\mathrm{Y}$ \\
\hline $\mathrm{N}$ & 2609 & 2609 & 906 & 906 & 2405 & 2405 & 2609 & 2609 \\
\hline Pseudo $\mathrm{R}^{2}$ & 0.29 & 0.57 & 0.34 & 0.86 & 0.41 & 0.35 & 0.60 & 0.34 \\
\hline First stage & & & & De & dent varia & e: trade & & \\
\hline $\begin{array}{l}\text { Factor } \\
\text { Endow. }\end{array}$ & $\begin{array}{c}-0.439^{* * *} \\
(0.013)\end{array}$ & $\begin{array}{c}-0.131^{* * *} \\
(0.012) \\
\end{array}$ & $\begin{array}{c}-0.362^{* * *} \\
(0.018) \\
\end{array}$ & $\begin{array}{c}-0.051^{* * * * *} \\
(0.018) \\
\end{array}$ & $\begin{array}{c}-0.382^{* * * *} \\
(0.014) \\
\end{array}$ & $\begin{array}{c}-0.382^{* * *} \\
(0.014) \\
\end{array}$ & $\begin{array}{c}-0.206^{* * *} \\
(0.014) \\
\end{array}$ & $\begin{array}{c}-0.206^{* * *} \\
(0.014) \\
\end{array}$ \\
\hline
\end{tabular}

Notes. Estimations by two stage pseudo maximum likelihood Poisson regression with regional fixed effects. Bootstrapped standard errors, clustered by country pairs in parenthesis. Significance level at $1 \%\left(\left(^{* * *}\right), 5 \%\left(^{* *}\right)\right.$ and $10 \%\left({ }^{*}\right)$. 


\section{Appendix}

Table A1: Countries included in the empirical analysis

\begin{tabular}{|c|c|c|c|c|}
\hline Country & Language & Colony & $\begin{array}{c}\text { Factor } \\
\text { Endowment }\end{array}$ & $\begin{array}{c}\text { Financial } \\
\text { Centre }\end{array}$ \\
\hline 1. Argentina & Spanish & $\mathrm{N}$ & $\mathrm{T}$ & $\mathrm{N}$ \\
\hline 2. Australia & English & $\mathrm{Y}$ & $\mathrm{T}$ & $\mathrm{N}$ \\
\hline 3. Austria & German & $\mathrm{N}$ & $\mathrm{K}$ & $\mathrm{N}$ \\
\hline 4. Belgium & French & $\mathrm{N}$ & $\mathrm{K}$ & $\mathrm{N}$ \\
\hline 5. Bolivia & Spanish & $\mathrm{N}$ & $\mathrm{T}$ & $\mathrm{N}$ \\
\hline 6. Brazil & Portuguese & $\mathrm{N}$ & $\mathrm{T}$ & $\mathrm{N}$ \\
\hline 7. Bulgaria & Bulgarian & $\mathrm{N}$ & $\mathrm{L}$ & $\mathrm{N}$ \\
\hline 8. Canada & $\begin{array}{l}\text { French, } \\
\text { English }\end{array}$ & $\mathrm{N}$ & $\mathrm{K}$ & $\mathrm{N}$ \\
\hline 9. Ceylon & English & Y & $\mathrm{T}$ & $\mathrm{N}$ \\
\hline 10. Chile & Spanish & $\mathrm{N}$ & $\mathrm{T}$ & $\mathrm{N}$ \\
\hline 11. China & $\begin{array}{l}\text { Chinese, } \\
\text { Japanese }\end{array}$ & $\mathrm{Y}$ & $\mathrm{T}$ & $\mathrm{Y}$ \\
\hline 12. Colombia & Spanish & $\mathrm{N}$ & $\mathrm{T}$ & $\mathrm{N}$ \\
\hline 13. Costa Rica & Spanish & $\mathrm{N}$ & $\mathrm{L}$ & $\mathrm{N}$ \\
\hline 14. Cuba & Spanish & $\mathrm{N}$ & $\mathrm{T}$ & $\mathrm{N}$ \\
\hline $\begin{array}{l}15 . \\
\text { Czechoslovakia }\end{array}$ & Czech & $\mathrm{N}$ & $\mathrm{K}$ & $\mathrm{N}$ \\
\hline 16. Denmark & Danish & $\mathrm{N}$ & $\mathrm{L}$ & $\mathrm{N}$ \\
\hline 17. Ecuador & Spanish & $\mathrm{N}$ & $\mathrm{T}$ & $\mathrm{N}$ \\
\hline 18. Egypt & English & $\mathrm{Y}$ & $\mathrm{T}$ & $\mathrm{N}$ \\
\hline 19. El Salvador & Spanish & $\mathrm{N}$ & $\mathrm{L}$ & $\mathrm{N}$ \\
\hline 20. Estonia & Estonian & $\mathrm{N}$ & $\mathrm{L}$ & $\mathrm{N}$ \\
\hline 21. Finland & Finnish & $\mathrm{N}$ & $\mathrm{L}$ & $\mathrm{N}$ \\
\hline 22. France & French & $\mathrm{N}$ & $\mathrm{K}$ & $\mathrm{Y}$ \\
\hline $\begin{array}{l}\text { 23. French West } \\
\text { Africa }\end{array}$ & French & $\mathrm{Y}$ & $\mathrm{T}$ & $\mathrm{N}$ \\
\hline 24. Germany & German & $\mathrm{N}$ & $\mathrm{K}$ & $\mathrm{Y}$ \\
\hline 25. Greece & Greek & $\mathrm{N}$ & $\mathrm{L}$ & $\mathrm{N}$ \\
\hline 26. Guatemala & Spanish & $\mathrm{N}$ & $\mathrm{T}$ & $\mathrm{N}$ \\
\hline 27. Holland & Dutch & $\mathrm{N}$ & $\mathrm{K}$ & $\mathrm{Y}$ \\
\hline 28. Hungary & Hungarian & $\mathrm{N}$ & $\mathrm{L}$ & $\mathrm{N}$ \\
\hline 29. India & English & $\mathrm{Y}$ & $\mathrm{T}$ & $\mathrm{N}$ \\
\hline 30. Indonesia & Dutch & $\mathrm{Y}$ & $\mathrm{T}$ & $\mathrm{N}$ \\
\hline 31. Ireland & English & $\mathrm{N}$ & $\mathrm{L}$ & $\mathrm{N}$ \\
\hline 32. Italy & Italian & $\mathrm{N}$ & $\mathrm{K}$ & $\mathrm{Y}$ \\
\hline 33. Jamaica & English & $\mathrm{N}$ & $\mathrm{T}$ & $\mathrm{N}$ \\
\hline 34. Japan & Japanese & $\mathrm{N}$ & $\mathrm{K}$ & $\mathrm{Y}$ \\
\hline 35. Latvia & Latvian & $\mathrm{N}$ & $\mathrm{L}$ & $\mathrm{N}$ \\
\hline 36. Lithuania & Lithuanian & $\mathrm{N}$ & $\mathrm{L}$ & $\mathrm{N}$ \\
\hline 37. Malaya & English & $\mathrm{Y}$ & $\mathrm{T}$ & $\mathrm{N}$ \\
\hline 38. Mexico & Spanish & $\mathrm{N}$ & $\mathrm{T}$ & $\mathrm{N}$ \\
\hline 39. Nicaragua & Spanish & $\mathrm{N}$ & $\mathrm{T}$ & $\mathrm{N}$ \\
\hline
\end{tabular}




\begin{tabular}{|l|c|c|c|c|}
\hline 40. Norway & Norwegian & $\mathrm{N}$ & $\mathrm{L}$ & $\mathrm{N}$ \\
\hline $\begin{array}{l}\text { 41. New } \\
\text { Zealand }\end{array}$ & English & $\mathrm{Y}$ & $\mathrm{T}$ & $\mathrm{N}$ \\
\hline 42. Peru & Spanish & $\mathrm{N}$ & $\mathrm{T}$ & $\mathrm{N}$ \\
\hline 43. Philippines & English & $\mathrm{Y}$ & $\mathrm{T}$ & $\mathrm{N}$ \\
\hline 44. Poland & Polish & $\mathrm{N}$ & $\mathrm{T}$ & $\mathrm{N}$ \\
\hline 45. Portugal & Portuguese & $\mathrm{N}$ & $\mathrm{L}$ & $\mathrm{N}$ \\
\hline 46. Rumania & Rumanian & $\mathrm{N}$ & $\mathrm{L}$ & $\mathrm{N}$ \\
\hline $\begin{array}{l}\text { 47. Union of } \\
\text { South Africa }\end{array}$ & English & $\mathrm{Y}$ & $\mathrm{T}$ & $\mathrm{N}$ \\
\hline 48. Spain & Spanish & $\mathrm{N}$ & $\mathrm{L}$ & $\mathrm{N}$ \\
\hline 49. Sweden & Swedish & $\mathrm{N}$ & $\mathrm{K}$ & $\mathrm{N}$ \\
\hline 50. Switzerland & French, & $\mathrm{N}$ & $\mathrm{K}$ & $\mathrm{N}$ \\
& $\begin{array}{c}\text { Italian, } \\
\text { German }\end{array}$ & & & \\
\hline 51. Turkey & Turkish & $\mathrm{N}$ & $\mathrm{T}$ & $\mathrm{N}$ \\
\hline 52. UK & English & $\mathrm{N}$ & $\mathrm{K}$ & $\mathrm{Y}$ \\
\hline 53. Uruguay & Spanish & $\mathrm{N}$ & $\mathrm{T}$ & $\mathrm{N}$ \\
\hline 54. US & English & $\mathrm{N}$ & $\mathrm{K}$ & $\mathrm{Y}$ \\
\hline 55. USSR & Russian & $\mathrm{N}$ & $\mathrm{T}$ & $\mathrm{N}$ \\
\hline 56. Venezuela & Spanish & $\mathrm{N}$ & $\mathrm{T}$ & $\mathrm{N}$ \\
\hline 57. Yugoslavia & Serbo- & $\mathrm{N}$ & $\mathrm{L}$ & $\mathrm{N}$ \\
\hline
\end{tabular}

\footnotetext{
${ }^{1}$ Correspondent banking was commonplace in some domestic banking systems. In the United States restrictions on inter-state branching meant that correspondent banking was an integral part of the US banking system up to the present. See for instance, James and Weiman, "Drafts to checks" and Osterberg and Thomson, "Banking consolidation”. In Britain small country banks used London banks as correspondents throughout the nineteenth century. The system came to an end by before WWI with the rise of giant clearing banks who absorbed most of the smaller fry. Collins, Money and Banking, 75-80.

${ }^{2}$ The extensive literature on merchant banks includes Chapman, Merchant Banking; and a host of company biographies including Ellis, Brown, Shipley \& Co.; Chernow, House of Morgan and The Warburgs; Ferguson, House of Rothschild and Siegmund Warburg; Ziegler, Barings; Burk, Morgan Grenfell; and Roberts, Schroders. ${ }^{3}$ Studies covering the development of national and international financial institutions from the late nineteenth century include Lescure, "Banking and finance"; Cottrell, Lange and Olsson, Centres and Peripheries; Verdier,
} 
Moving Money; Easton, "Growth of banking"; le Cheminant, Colonial and Foreign Banking; Eichengreen, Globalising Capital; Cassis, Capitals of Capital; Goldsmith, Financial Structure and Development; League of Nations, Commercial Banks; Cameron et. al., Banking in the Early Stages of Industrialization.

${ }^{4}$ The most important studies of the emergence of MNBs include Baster, Imperial Banks and International Banks; Cameron \& Bovykin, International Banking; Casson, "Evolution"; Jones, Banks as Multinationals; British Multinational Banking and "British multinational banking"; Wilkins, History and Maturing.

${ }^{5}$ Battilossi, "Determinants of multinational banking”, 370 .

${ }^{6}$ Dunn, Foreign Investments, 52-53.

${ }^{7}$ Baster, International Banks, p. 24.

${ }^{8}$ Williamson, Economic Institutions, chapters 2-8.

${ }^{9}$ Williamson, Economic Institutions, chapters $2 \& 3$.

${ }^{10}$ Merrett, "Global reach".

${ }^{11}$ Dunning and Lundan, Multinational Enterprises, chapter 5.

${ }^{12}$ League of Nations, Commercial Banks, various editions.

${ }^{13}$ Jones, British Multinational Banking.

${ }^{14}$ Mira Wilkins' work on US banks abroad is an exception to this statement, see Maturing and History.

${ }^{15}$ The terms agent and correspondent had the same meaning. See Michie, "Banks and securities markets"; "Global financial centre" and "Centre for international banking".

${ }^{16}$ It was first published by Waterlow and Sons under the title of Palgrave's Colonial and Foreign Directory before becoming Banking Almanac, Directory, Year Book and Diary under the editorship of D. Morier Evans, who was succeeded by R. H. Inglis Palgrave from 1875 until 1919. See Howe, "Palgrave, Sir (Robert Harry) Inglis". Thomas Skinner became publisher in 1920 and name changed to Bankers' Almanac.

${ }^{17}$ Nishimura, Decline, 9 .

${ }^{18}$ Battilossi, "Determinants of multinational banking", 365-6.

${ }^{19}$ Mollan "International correspondent networks", 218-19.

${ }^{20}$ Mollan "International correspondent networks", 219.

${ }^{21}$ Bankers Almanac, 1901 and 1917, "Note to Readers".

${ }^{22}$ Bankers' Almanac, 1924/25, "Preface".

${ }^{23}$ Baster, "International acceptance"; Spalding, Foreign Exchange, chapter XIX.

${ }^{24}$ Michie, 'The City of London as a centre”, Table 3.13, 78. 
${ }^{25}$ Michie, "The City of London as a global”, 53.

${ }^{26}$ For example the Banco Frances del Rio de la Plata, used Credit Lyonnais as correspondent in London. This relationship was entered as an Argentinian bank having a CB relationship with a French bank.

${ }^{27}$ Matthews, P. W., The Bankers' Clearing House, What it is and What it Does, London: Sir Isaac Pitman, 1921, 18.

${ }^{28}$ League of Nations, Network, Appendix III, 106-71.

${ }^{29}$ Cassis, Capitals of Capital, chapters 4, 6 \& 7.

${ }^{30}$ League of Nations, Commercial Banks, 1937, 110 \& 123. Japanese bank failures were linked to structural weaknesses dating back to WWI, see Goldsmith, Financial Development of Japan, 83-84 \& 119.

${ }^{31}$ See for example Melzer, "The Great Depression" and Rustici "Banking crises".

${ }^{32}$ For instance the Merchants National Bank of Boston, a US bank, had 20 correspondents in 15 countries; the Bank of Nova Scotia, a Canadian bank, had 64 correspondents in 12 countries; Ernesto Tornquist \& Co. Limitada, an Argentinian bank, had 18 CBs in 3 locations. If a bank used a non-British one as correspondent in London, such as the Swiss Wegelin \& Co. using the French Comptoir National d'Escompte de Paris located in London, we have credited such relationship to the Switzerland-France pair, following a nationality and not a location criterion.

33 "The City of London as a global", 52; and "The City of London as a centre", 16-19.

${ }^{34} \mathrm{We}$ use the term agent in the sense that it is used in the principal-agent literature. Pratt and Zeckhauser, "Principals and agents", 1-24.

${ }^{35} \mathrm{We}$ are excluding minor and esoteric services such as safe deposit boxes and the issuance of currency.

${ }^{36}$ Huertas, "US multinational banking, 248.

${ }^{37}$ Osterberg and Thomson, "Banking consolidation”, 10.

${ }^{38}$ Merrett, "Global reach", 72-76

${ }^{39}$ Merrett, "Global reach", 76.

${ }^{40}$ Correspondent banking within the USA used deposits as payment. See James and Weiman, "From drafts", 78; Lawrence and Lougee, "Determinants", 359. In international correspondent banking it seems to have been a combination of deposits and fees, see Merrett "Global reach", 79-80.

${ }^{41}$ Osterberg and Thomson, "Banking consolidation", 9.

${ }^{42}$ Pratt and Zeckhauser, "Principles and agents", 3. 
${ }^{43}$ Battilossi, "The determinants"; see also Jones, British Multinational Banking; "Competitive advantages";

"British multinational banking".

${ }^{44}$ Tschoegl, "International retail banking."

${ }^{45}$ Jones, "Free-standing banks."

${ }^{46}$ Jones, British Multination Banks; Baster, Imperial Banks.

${ }^{47}$ There were three exceptions, the Bank of New Zealand [1872], the Comptoir National D'Escompte De Paris [1880], and the Yokohama Specie Bank [1915], none of which offered retail banking services. Moore and Barton, Banking in New Zealand, 33; Butlin, Hall and White, Australian Banking, 104-6.

${ }^{48}$ Australian banks with branches in London enjoyed the privilege of being able to "issue sterling acceptances.", Stern, United States, 182. They were also members of the British Bankers' Association from its establishment in 1919. Collins, Money and Banking, 211. Merrett, "Paradise lost?" Table 4.2, 67 and Table 4.3, 69.

${ }^{49}$ Baster, Imperial Banks, 160-189.

${ }^{50}$ Some Australian banks opened branches in New Zealand (the Bank of Australasia [1864], Union Bank of Australia [1839], Bank of New South Wales [1861] and Commercial Bank of Australia [1912]), Papua New Guinea (Bank of New South Wales [1901]) and Fiji (Union Bank of Australia [1880-1895], and Bank of New South Wales [1901]). Butlin, ANZ Bank, 153-72, 163-6 \& 247-8; Holder, Bank of New South Wales, 249-51, 509-14; Wood, Commercial Bank, 222.

${ }^{51}$ Following customers abroad is a key explanation of contemporary behaviours by MNBs. See Williams, "Defensive expansion" and Esperanca and Gulambusse, "(Re)testing".

${ }^{52}$ Merrett, "Paradise lost?", 72-3.

${ }^{53}$ Merrett, "Australian banks", 177-8. On 31 August 1926 the ten staff in Bill Department at the Union Bank of Australia's head office in Melbourne had a book of 9,147 foreign bills awaiting payment or collection. Union Bank of Australia "Melbourne Branch": 48.

${ }^{54}$ Ville, "Relocation".

${ }^{55}$ The bank signalled to its local rivals that it would "begin its operations here only in a small way". Daily Telegraph, 10 June 1915: 4.

${ }^{56}$ Commonwealth Bureau of Census and Statistics, Trade and Customs, Table XIII: 434-5; and Overseas Trade, Table X: 494-5.

${ }^{57}$ As reported in Merrett, "Global reach", 71. 
${ }^{58}$ Estimates of fees charged to customers for international funds transfers and collection, and foreign exchange charges, by the Union Bank of Australia and the English, Scottish \& Australian Bank are reported in Merrett, "Global reach", 80. The balance of payments data is drawn from Butlin, Australian Domestic Product, Tables $263 \mathrm{~A}, \mathrm{~B}$ and $264 \mathrm{~A}, \mathrm{~B}, 442-3$.

${ }^{59}$ The operating margin figure of $£ 8.05 \mathrm{~m}$ comes from Butlin, Hall and White, Australian Banking, Table 6, 12930, and Table 51, 493-4. The aggregate annual fee for operating a check account, ten shillings per annum, was reached by extrapolating the number of customers using check accounts and the average value of each account at the Melbourne office of the Union Bank in 1921 to produce a national total of the number of accounts for 1935. "Melbourne branch". The amount collected from 'in land exchange' and the judgement that the system did not cover its costs see Giblin, Central Bank, 258.

${ }^{60}$ Feenstra, Markusen \& Rose, "Using the gravity equation"; Portes, Rey \& Oh, "Information and capital flows"; and Hejazi "Reconsidering".

${ }^{61}$ Battilossi, "Determinants of multinational banking"; Papaioannou, "What drives international bank".

${ }^{62}$ Goldsmith reports that by the inter-war period there had been a 'decline in the relative importance of foreign banks in virtually all areas in which they operated'. Goldsmith, Financial Structure: 364.

${ }^{63}$ Using bank-pairs (instead of country-pairs) as units of reference and choosing an alternative empirical framework (for example network analysis) would have been a valid alternative. However, the type and amount of data that could be collected would prevent us both from undertaking comprehensive econometric testing and from including such a large number of countries.

${ }^{64}$ Reed, The Preeminence, 1-14.

${ }^{65}$ Eichengreen and Irwin, "Slide to protectionism".

${ }^{66}$ Melitz, "North, South and distance", 983.

${ }^{67}$ Skinners' The Bankers' Almanac.

${ }^{68}$ Mitchell, International Historical Statistics. We converted Mitchell nominal GDP data in local currency units into nominal US\$ using the PPP rates, generated using prices reported in League of Nations (1937). We have subsequently used the US GDP deflator in 1990 to transform nominal GDP in US\$ into Geary-Khamis dollars.

${ }^{69} \mathrm{http}: / /$ www.ggdc.net/maddison/oriindex.htm.

${ }^{70}$ League of Nations, Network, $16-21$ and 106-71. 
${ }^{71}$ Silva and Tenreyro, "Log of gravity". This methodology ensures the estimation of robust and consistent results since it deals with two main data issues: heteroskedasticity in $e_{i j}$ and the presence of a large number of zeros in $x_{i j}$

${ }^{72}$ Silva and Tenreyro, "Simulation evidence".

${ }^{73} \mathrm{~A}$ country's economic and financial size, as well as the other political/institutional variables specified in equation (2), could influence both trade and banking activities.

${ }^{74}$ Battilossi, "Determinants of multinational banking", 373.

${ }^{75}$ Chitu, Eichengreen \& Mehl, "History, gravity and internal finance”, 110.

${ }^{76}$ This classification criterion has been guided by Williamson, "Land, labor and globalization" and the League of Nations Network, 21-36.

${ }^{77}$ The formula to compute the effect of a coefficient is $e^{\beta}-1$, where $\beta$ is the estimated parameter. This represents the percentage change in $\mathrm{CB} / \mathrm{MNB}$ given a percentage change in the regressors (or for switching from 0 to 1 in the case of dummy variables).

${ }^{78}$ For the importance of distinguishing between statistical and economic significance see McCloskey and Ziliak "The standard error".

${ }^{79}$ Other institutional factors are captured by regional fixed effects. Indeed, it would be more appropriate to add home and host country fixed effects (rather than region-specific ones), in order to account for country-specific factors that may have affected a bank's strategy to expand cross-border, such as legal barriers. However, due to the nature of our cross-sectional dataset with 57 x 56 country-pairs, estimating home and host country-fixed effect is not feasible, since the number of parameters to be computed would be too large. This is because the Hessian variance and covariance matrix needed to calculate the standard errors runs in convergence problems due to the large number of parameters to be estimated.

${ }^{80}$ Michie, "Banks and securities markets"; "Global financial centre" and "Centre for international banking".

${ }^{81}$ Tschoegl, "Ideologies and changes".

${ }^{82}$ Clemens and Williamson, "Tariff-growth correlation".

${ }^{83}$ Magee \& Thompson, Empire and globalisation.

${ }^{84}$ Goldsmith, Financial Structure, Table 4-13, 209.

${ }^{85}$ Khoury, Deregulation; Channon, Global Banking.

${ }^{86}$ Naughton and Chan, "Correspondent banking". 